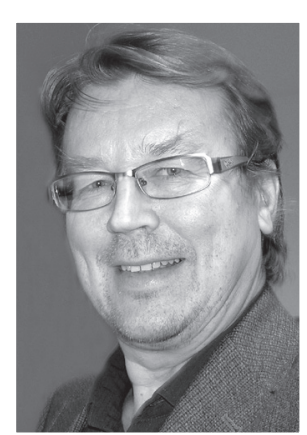

\title{
PÄÄKIRJOITUS
}

\section{PolitiIKKA PALAILEE POLITIIKKAAN}

änestysaktiivisuus on demokratian toi-
mivuuden keskeinen mittari. Demokra-
tia toimii huonosti, jos kansalaiset eivät
osallistu valtaa käyttävien ja päätöksiä tekevien valintaan. Pitkän aikavälin tarkastelussa demokratian toimivuus on monissa kehittyneissä maissa rapautunut. Suomessa eduskuntavaalien äänestysaktiivisuus oli 1960-luvulla 85 prosenttia. 1970-luvulla se laski 80 prosenttiin ja painui 1990-luvulla alle 70 prosentin, missä se pysyi myös 2000-luvun ensi vuosikymmenen. Vuoden 2011 "protestivaalit" innostivat aktiivisuuden nousuun ja äänestäminen kohosi 70 prosenttiin. Äänestysaktiivisuuden kasvu ei ollut mikään hurja, mutta puolueiden edustajapaikkoihin vaalilla oli huomattava vaikutus.

Yhdenlainen demokratian pohjanoteeraus koettiin vuonna 2009 europarlamenttivaaleissa. Suomessa äänestysaktiivisuus jäi 40 prosenttiin. Pelkästään äänestysaktiivisuudella arvioiden eurodemokratia toimii huonosti. Se on myös kansalaisten käsitys. Toukokuussa 2011 tehdyn tutkimuksen mukaan vain joka neljäs suomalainen ajattelee, että demokratia toimii Euroopan unionissa hyvin. Kansalaiset kokevat europarlamentin päätöksenteon etäisenä ja euroopanlaajuiset asiat monimutkaisena ja vaikeasti hallittavana kokonaisuutena. Järkiperäinen mielipiteen muodostaminen vaatii runsaasti tietoa ja ajan käyttämistä politiikan seuraamiseen. Valitsijan osa ei ole helppo enää kotimaankaan politiikassa. Kansallisvaltiot ovat osa suurempia yhteisöjä, missä yhden maan ratkaisuilla on seurauksia muissa maissa ja koko kansainvälisessä yhteisössä.

Kansalaisten mielenkiinnon hiipumiselle on löydettävissä monenlaisia syitä. Puolueet ovat alkaneet näyttää liiaksi toisensa kaltaisilta yleispuolueilta. Varsinkin suuret puolueet ovat kalastelleet samoilla vesillä samoista äänestäjistä. Silloin on parasta pitää kieli keskellä suuta ja varoa ärsyttämästä ketään. Puolueet ovat onnistuneet piilottamaan aatteensa. Suuret puolueet ovat kaupanneet äänestäjille itseään asianajotoimistoina, jotka lupaavat ottaa tehtäväkseen ajaa mitä hyvänsä, mitä uskovat äänestäjien kulloinkin haluavan. Puoluetoiminnasta ja politiikasta on tullut elinkeino. Aikoinaan puolueet perustettiin aatteen ympärille. Ensin oli aate, jonka ympärille kokoontuivat kannattajat. Nykyisten politiikkaa elinkeinonaan harjoittavien puolueiden ensisijainen tavoite on mahdollisimman suuri äänimäärä. Puolue on kauppa ja äänestäjät sen asiakkaita: kun äänestät meitä, me lupaamme mitä vain haluat.

Äänestäjistä on alkanut tuntua, että onpa eduskunnassa ja hallituksessa keitä hyvänsä, harjoitettuun politiikkaan sillä ei ole vaikutusta. Politiikasta on tul- 
SELVÄSTI NYKYISTÄ VAHVEMMIN VAPAAN SIVISTYSTYÖN

ASIALISTALLE."

lut vaihtoehdotonta asioiden hoitamista, ja lähivuosien poliittiset päätökset valmistellaan ministeriöissä jo ennen kuin vaalit on pidetty ja uusi hallitus saatu koottua. Virkamiesvalta on politiikassa vahvistunut, kun poliittinen eliitti on vahvistanut asemaansa valtion virkoihin nimittämillään asiantuntijoilla.

Vuoden 2011 eduskuntavaalit voivat hyvinkin jäädä historiaan politiikan epäpolitisoitumisen lakipisteenä. Perussuomalaiset onnistui kanavoimaan politiikan vastaisuuden omaksi kannatuksekseen. Politiikan palauttivat politiikkaan ne, joiden ajateltiin olevan vähiten kiinnostuneina ja huonoiten perillä politiikasta. Poliittisesti aktivoitunut politiikan vastaisuus kohdistuu sen kaltaiseen politiikkaan, jota Suomessa on harjoitettu viime vuosikymmenet - vaihtoehdottomaksi naamioituun valtionhoitamiseen, jossa pohjaltaan poliittiset päätökset on haluttu esittää asiantuntijatietoon perustuvina teknisinä ratkaisuina sosiaalisiin ja talouden ongelmiin. Vaalitulos heijastaa myös äänestäjien kasvanutta tyytymättömyyttä poliittisen eliitin piirissä paljastuneeseen korruptoituneisuuteen ja kansalaisten moraalitajun vastaiseen toimintaan.

Äänestysaktiivisuuden kasvua on tervehditty demokratian voittona. Edellyttääkö demokratia kansalaistaitoja? Ei, mikäli ainakin puolet kansalaisista käy äänestämässä vaaleissa ja vaalitulosta pidetään legitiiminä. Äänestäjät saavat valita ehdokkaansa millä perusteella haluavat. Mutta kyllä kai kansalaistaidot ja -tiedot hyväksi olisivat. Järjestelmää, jossa valitsijat seuraavat politiikkaa ja perehtyvät yhteiskunnallisiin asioihin, ymmärtävät monimutkaistuvan maailman lainalaisuuksia sekä osaavat perustella kantansa tosiasioihin ja arvoihin vedoten, pidetään toivottavampana kuin järjestelmää, jossa kansalaiset valitsevat edustajansa mutu-tuntumalla tai hetken mielijohteesta, tai populististen yhden asian lupausten perusteella.

Vuonna 2010 Turun yliopistossa tarkastettu väitöstutkimus Tietääkö kansa? (Lauri Rapeli) paljastaa suomalaisten politiikkatietämyksen verraten vähäiseksi. Suurin osa ei pysty nimeämään hallituksessa olevia puolueita. Väestöryhmien ja eri puolueita kannattavien ihmisten välillä on suuria eroja politiikkatietämyksessä. Korkeamman koulutuksen saaneet tietävät enemmän kuin vähemmän koulutetut. Johtavassa asemassa tai toimihenkilöinä työskentelevien tietämys on selvästi parempi kuin muilla ammattiryhmillä. Alle kolmekymppisten tietämys on vähäisempää kuin keski-ikäisten tai varttuneempien tietämys. Nukkuvien puolue nukkuu paljolti tiedon puutteen vuoksi.

Poliittinen osallistuminen ja kansalaistaidot on laiminlyöty koulutuksessa. Aikuiskoulutuksen puolella tietämyksen kohentaminen lankeaisi luontevimmin vapaan sivistystyön tehtäväksi. Yhteiskunnallisten asioiden harrastuksen ja poliittisen toiminnan arvostus olisi syytä nostaa selvästi nykyistä vahvemmin vapaan sivistystyön asialistalle.

Heikki Silvennoinen 